Available online at www.sciencedirect.com

ELSEVIER

\title{
Effects of land-use on Collembola diversity patterns in a Mediterranean landscape
}

\author{
José Paulo Sousa,*, Maria Manuela da Gama ${ }^{a}$, Cristina Pinto ${ }^{a}$, \\ António Keating ${ }^{a}$, Filipa Calhôa ${ }^{a}$, Marco Lemos $^{a}$, Catarina Castro ${ }^{a}$, \\ Tiago Luz ${ }^{a}$, Pedro Leitão ${ }^{b}$, Susana Dias ${ }^{b}$
}

\author{
${ }^{a}$ Departamento de Zoologia, Instituto do Ambiente e Vida, Universidade de Coimbra, \\ Lg. Marquês de Pombal, P-3004-517 Coimbra, Portugal \\ ${ }^{\mathrm{b}}$ Centro de Ecologia Aplicada Prof. Baeta Neves, Instituto Superior de Agronomia, Tapada da Ajuda, \\ P-1349-017 Lisboa, Portugal
}

Received 17 September 2002; accepted 6 June 2004

\section{KEYWORDS \\ Collembola; \\ Landscape change; \\ Bioindicators; \\ Habitat diversity; \\ Soil-use types; \\ Cork-oak forests}

\begin{abstract}
Summary
Collembola communities were sampled along a gradient of soil-use intensification in a typical Mediterranen landscape dominated by cork-oak. This gradient ranged from a land-use unit (LUU1) dominated by closed oak forest with minimum intervention to an unit entirely composed of a monoculture crop submitted to frequent anthropogenic disturbances (LUU6), passing through LUUs with managed woodland (LLU2) or dominated by open cork-oak areas and pastures (LUU3 and LUU5). The Collembola community in the overall area was dominated by a few abundant species, mainly Isotomidae, present in almost all units. Abundance, diversity and species richness decreased along the gradient, with the agricultural site presenting an impoverished community. Diversity descriptors were positively and significantly correlated with habitat diversity, measured on the basis of the proportion of the different soil-use types present at each land-use unit. Multivariate analysis revealed changes in Collembola community composition between the LUUs, with LUU6 detaching from the rest. LUU1 and LUU2, despite the less diverse community of the latter, formed a separate group from the remaining two units (LUU3 and LUU5). Species composition in all these units was mainly determined by soil-use types present at each LUU (open cork-oak land and pastures vs. closed cork-oak areas), the proportion of the different soil-use types and the different management practices adopted for each soil use. Overall analysis revealed that Collembola reacted to changes in the landscape structure, with community composition giving a more robust response than diversity indices.
\end{abstract}

(c) 2004 Elsevier GmbH. All rights reserved.

${ }^{*}$ Corresponding author.

E-mail address: jps@zoo.uc.pt (J.P. Sousa). 


\section{Introduction}

In terrestrial environments, the status of biodiversity at local or regional level is influenced by driving forces such as agriculture, forestry and urbanisation. These forces cause changes in land-use (e.g., fragmentation, intensification, afforestation, reforestation), which directly affect diversity patterns of living organisms. To develop a set of effective tools, able to monitor these changes, is one of the priorities within the EU, as stated in the Convention of Biological Diversity. The study presented here is integrated in the EU funded project BIOASSESS, the goal of which is to develop a set of "biodiversity assessment tools" to monitor changes in biodiversity patterns due to policy-derived changes in soil use. Among others (plants, lichens, soil macrofauna, carabids, butterflies and birds), Collembola were chosen as a study group due to their acknowledged representativity in the soil system in terms of biodiversity and due to their ability to respond to a wide range of disturbance factors.

Collembola respond to changes in soil chemistry (Hågvar and Abrahamsen, 1984), namely soil pH (Vilkamaa and Huhta, 1986; Van Straalen and Verhoef, 1997; Ponge, 2000; Loranger et al., 2001), and changes in microclimatic and microhabitat conditions like moisture (Poinsot-Balaguer, 1975; Verhoef and Van Selm, 1983; Pflug and Wolters, 2001), amount and quality of litter (Ponge et al., 1993; Cortet and Poinsot-Balaguer, 1998; Hasegawa, 2002) and humus type (Ponge and Prat, 1982; Chagnon et al., 2000). Also, different vegetation communities host different species assemblages of Collembola (Pozo et al., 1986; Setälä et al., 1995; Gama et al., 1997; Benito and Sanchez, 2000); this is particularly true when comparing open and closed habitats (Bonnet et al., 1976, 1977; Ponge, 1980, 1993).

Collembola communities also react to different forest and agricultural activities. Reforestation with exotic tree species is known to cause a decrease in diversity (Bonnet et al., 1977; Gama et al., 1994; Deharveng, 1996; Pinto et al., 1997; Sousa et al., 1997; Barrocas et al., 1998; Sousa et al., 2000) and logging may cause a disruption on the biocenotic equilibrium of Collembola communities over several years (Bengtsson et al., 1997), depending on the regime adopted. Crop management practices can also lead to changes in species assemblages and diversity (Nakamura, 1988; Dekkers et al., 1994; Filser et al., 1995; Reddy et al., 1996; Loranger et al., 1999; Frampton, 2000; Alvarez et al., 2001; Gardi et al., 2002). Moreover, landscape configuration (e.g., heterogeneity, frag- mentation) and the type of use (e.g., pasture, farm forest) also regulates Collembola community composition (Filser et al., 1996; Lauga-Reyrel and Deconchat, 1999; Alvarez et al., 2000; Dombos, 2001).

However, and despite the information available, studies evaluating the use of Collembola as bioindicators of changes in soil intensification at landscape level are lacking. The results presented here correspond to the data obtained for Collembola on the Portuguese sites of the BIOASSESS project. Collembola diversity patterns were evaluated along a gradient of land-use intensification in a typical Mediterranean landscape dominated by Quercus suber. The gradient ranged from areas with cork-oak forest with minimum disturbance, to agricultural plots with monoculture crops, passing through areas with managed parklands and pastures. The main goal was to detect changes in biodiversity patterns and community composition along this land-use gradient and to evaluate the use of Collembola as tools to depict changes at landscape level.

\section{Materials and methods}

\section{Site description}

The study was located in the consolidated alluvial plain of the Tagus river (left bank), $20 \mathrm{~km}$ east of Lisbon, Portugal (ca $4250^{\circ} \mathrm{N} 5150^{\circ} \mathrm{E}$ ). The altitude ranges from 8 to $45 \mathrm{~m}$. The climate of the area is typically Mediterranean: about $80 \%$ of relative humidity, no frost; annual rainfall averages $574 \mathrm{~mm}$ (concentrated in November-February) while mean temperature is $16.3^{\circ} \mathrm{C}(5.9$ and $28.8^{\circ} \mathrm{C}$ as extreme mean temperatures in January and July, respectively) (data for Montijo air base, $5 \mathrm{~km}$ away).

The area was covered by a unique kind of woodland - the cork-oak "montado" - a human modified natural vegetation resulting from tree clearing of evergreen oak forests and ground ploughing during the last three centuries (Pulido et al., 2000). "Montados" exhibit a diverse array of management combinations including extensive rearing of sheep, cows, pigs and goats, as well as periodic ploughing of the land for cereal and hay, shrub removal and pruning of the trees (Diaz et al., 1997). Oak trees in "montados" are more or less sparsely distributed over an understory composed of patches of grasslands and shrubs. The dominance of each of these elements varies according to the management intensity of the area. "Montado" 
covers an important area of the Iberian Peninsula and supports a high biological diversity (Pulido et al., 2000).

The study was conducted in five land-use units (coded LUU1 to 6) of $1 \mathrm{~km}^{2}$ each, selected according to a possible gradient of soil-use intensity. Four sites are typical woodland and one has been an agricultural land for at least 50 years. Woodland sites differed in heterogeneity of strata, tree volume and understory vegetation, and also in grazing intensity, all conditioned by the different management practices adopted. Soil-use types at each LUU were defined based on the visual interpretation of aerial photographs of the sites and further validation in the field. Five dominant soil-use types were identified: closed cork-oak formation (with high tree density), open cork-oak formation (trees are more scattered distributed), shrub areas (dominated by a dense shrub cover and very low tree density), pasture or grassland areas (dominated by pastures or grass species, and also with low tree density) and crop areas.

LUU1 is located in a buffer zone for military purposes (Campo de Tiro de Alcochete). This situation resulted in a low level of management of the area, with just minor interventions, and consequently a high degree of habitat heterogeneity. The tree stratum is dominated by cork-oak (Q. suber), although maritime pine (Pinus pinaster) and umbrella pine ( $P$. pinea) are present, being equally abundant in some sub-areas (resulting in mixed formations). Although several fire-breaks are periodically cleaned in the area, no other understory management occurred in the past 10-15 years, resulting in a dense shrub layer dominated by Cistus salvifolius, C. psilosephalus, Phillyrea angustifolia, Calluna vulgaris and Ulex australis. Natural regeneration of cork-oak and maritime pine is visible in some areas. Cork removal is traditionally done on a 9-year rotation, during the months of July-August. Grazing and hunting are residual. Locally, we can identify small temporary wetlands, priority habitats for biological conservation, potentially included in the Habitats directive. When present, the grass layer is dominated by Juncus pygmaeus, J. capitatus and Brachypodium phoenicoides.

The other LUUs, located $5 \mathrm{~km}$ north of LUU1 are privately owned by an agroforestry company Companhia das Lezírias - for multiple use, resulting in a more intensive managing system. In LUU2, cork-oak trees are more densely distributed in the southern part; pruning has been done in the past 2 years; understory is generally well developed, dominated by $C$. salvifolius, Lavandula luisieri and $U$. australis. Shrub removal occurs every 7-8 years, and the northern sub-area was cleaned more recently than the rest.

LUU3 is also a cork-oak "montado" with patches of natural grassland, located near the southern limit and in the drainage sites (torrential streams); C. ladanifer and C. salvifolius, having at least 8 years old, dominated the shrub layer. The grass layer is dominated by Agrostis castellana, Briza maxima, Trifolium sp. Chaetopogon fasciculatus, B. phoenicoides, Chamaemelum nobile and J. bufonius. Grazing by cows is just occasional.

LUU5 represents an area with patches of open "montado" with shrub understory dominated by $C$. ladanifer, $C$. salvifolius and $U$. australis and two different kinds of grasslands. One is an improved grassland since 1999, with a mixture of different clovers (Trifolium angustifolium, T. campestre, T. glomeratum, $T$. repens and $T$. strictum) and the other is a by-product of Triticale (Triticum $\times$ Secale) sown in 1999; J. bufonius, A. castellana, B. maxima, C. fasciculatus and $C$. nobile are common. On both, extensive grazing occurs during winter (January-February) and partially at the end of summer.

LUU6 is a homogeneous and intensively irrigated field since 1988. Alfalfa (Medicago sativa), utilised as fodder, was sown for the first time in April 2001. Mowing occurs 4-5 times each year (April-August), in the expected 7 years of hay exploitation. Three mineral fertilisations $(\mathrm{N}, \mathrm{P}, \mathrm{K}-8,24,24)$ of $300 \mathrm{~kg} /$ ha are made each year.

\section{Collembola sampling and sample processing}

On each of the five LUUs a grid composed of 16 squares $(4 \times 4)$, each $200 \mathrm{~m}$ wide, was defined based on the analysis of the aerial photographs. On the centre of each square a sampling point was defined and marked in the field with the help of a GPS apparatus.

Sampling took place between April and May 2001. At each sampling point Collembola were sampled taking a sample core $(5 \mathrm{~cm}$ diameter) including the organic horizon (when present) plus $5 \mathrm{~cm}$ of the mineral soil. From each core sample, the organic and mineral fractions were separated into two samples. They were placed in plastic bags and kept cool until transport to the laboratory (within 2 days). Simultaneously, the depth of the organic horizon on the point was measured.

Back in the laboratory, and before extraction of the animals, samples were weighed. Collembola were extracted by placing samples in a Macfadyen high-gradient extractor during 1 week. Afterwards, animals were preserved in $80 \%$ ethyl alcohol, sorted 
and identified. Samples were then processed (weighed and sieved) to determine moisture content (dried overnight at $105^{\circ} \mathrm{C}$ ), soil pH (in $1 \mathrm{M} \mathrm{KCl}$ $1: 6 \mathrm{v}: \mathrm{v}$ ), carbon (Anne's method) and nitrogen (Kjeldahl's).

\section{Data analysis}

Physical and chemical parameters, Collembola densities and number of species found at each LUU were compared by an ANOVA, followed by an SNK test. If assumptions of homogeneity of variances and normality (verified previously using Bartlett and Kolmogorov-Smirnov tests, respectively) were not met, data was transformed according to Zar (1996). In those cases where, even after transformation, data did not meet these assumptions, the Kruskal-Wallis test was used instead (followed by a Dunn's test). Statistical calculations were made using the SigmaStat software (SPSS, 1995).

For each LUU species diversity (ShannonWiener), evenness (Pielou), and species richness (Margalef) were calculated according to Magurran (1991). Diversity measures were correlated with habitat diversity (see below) using the Pearson coefficient calculated with the SigmaStat software (SPSS, 1995).

Habitat diversity at each LUU was calculated based on the proportion of different soil-use types present using the Shannon-Wiener index.

Multivariate techniques were used in several situations. To associate species to LUUs, a canonical correspondence analysis (CCA) was done using log transformed data and based on the "sampling points vs. taxa" and "sampling points vs. LUU" data matrices. A similar analysis was performed to constrain species to the different soil-use types, based on the matrices "sampling points vs. taxa" and "sampling points vs. soil-use types". On both CCAs taxa having a total abundance lower than five specimens and appearing only in one sample were discarded for analysis; also the statistical significance of the canonical axes was evaluated by a Monte Carlo permutation test. CCAs were performed in CANOCO 4.0 software (Ter Braak and Smilauer, 1998).

Another type of multivariate technique was used to detect significant differences in community composition between LUUs. The SIMAN analysis (Sousa and Gama, 1994) was performed based on the Bray-Curtis similarity index (Faith et al., 1987) and considering LUU1 as the control plot. In this type of analysis the average similarity among control samples is compared with the different average similarities between "treatment vs. control" samples (here LUU1 vs. LUUx). Significant differences indicate differences in species assemblages between LUUs under comparison. Similarity matrix was obtained using NTSYS-pc software (Rohlf, 1997) based on log transformed data and using "sampling points vs. taxa" matrix as raw data. Afterwards, similarity values were compared by an ANOVA followed by a Dunnett test. Normality and homoscedasticity were checked as referred above (Zar, 1996). Analysis was done using the SigmaStat software (SPSS, 1995).

For all analysis, samples from both horizons of each sampling point were pooled.

\section{Results}

\section{Physical and chemical characterisation and habitat diversity}

Physical and chemical characterisation of the different sites revealed several significant differences in some of the parameters measured (Table 1). These occurred more at the mineral horizon, where most of the differences were found between the woodland areas (LUU1-LUU5) and the agricultural site (LUU6). The exception was observed for the water content, with LUU2 presenting the lowest value. This low water content was also observed in the organic horizon, and could have been caused by the late sampling (this was the last site to be sampled and the soil was already too dry). However, the configuration of the vegetation in this site, with a general low litter cover, and also the absence of water bodies in the proximity, could have also contributed to more dry conditions.

Habitat diversity based on the proportion of the different soil-use types is expressed in Table 2. The highest value was found for LUU5, followed closely by LUU1 and LUU3. However, LUU1 is dominated by closed forest areas, while in LUU5 open areas prevail; LUU3 makes the transition between the two. The lowest habitat diversity was observed in LUU6, the crop field, followed by LUU2. The low value obtained for this landscape unit is due to the strong distribution of sampling points among two habitat types.

\section{Collembola: abundance, taxonomic profile and diversity}

A total of 2780 individuals, separated into 63 taxa, were identified over all landscape units. LUU1 presented the highest abundance and the highest 
Table 1. Physical and chemical characterisation of the different LUUs (average and SD)

\begin{tabular}{|c|c|c|c|c|c|c|c|}
\hline & LLU1 & LLU2 & LLU3 & LLU5 & LLU6 & $\mathrm{F}$ or $\mathrm{H}$ & $p$ \\
\hline \multicolumn{8}{|l|}{ Organic horizon } \\
\hline Water content (\%) & $66.5(29.8)^{a}$ & $15.3(10.5)^{\mathrm{a}}$ & $141.3(81.5)^{\mathrm{b}}$ & $57.8(29.9)^{a}$ & & 9.82 & $<0.001$ \\
\hline Carbon (\%) & $21.36(13.83)$ & $19.37(4.72)$ & $22.98(9.35)$ & $21.25(20.15)$ & & 0.10 & n.s. \\
\hline Nitrogen (\%) & $0.29(0.09)$ & $0.23(0.04)$ & $0.32(0.12)$ & $0.29(0.09)$ & & 1.4 & n.s. \\
\hline $\mathrm{C} / \mathrm{N}$ ratio & $72.95(38.14)$ & $85.00(22.01)$ & $75.28(29.07)$ & $83.21(94.90)$ & & 0.12 & n.s. \\
\hline Thickness $(\mathrm{cm})$ & $3.9(1.3)^{\mathrm{a}}$ & $2.0(1.4)^{\mathrm{b}}$ & $2.6(1.3)^{a, b}$ & $2.4(1.6)^{\mathrm{a}, \mathrm{b}}$ & & 3.58 & $<0.05$ \\
\hline \multicolumn{8}{|l|}{ Mineral horizon } \\
\hline Water content (\%) & $17.4(8.8)^{\mathrm{a}}$ & $5.6(3.9)^{\mathrm{b}}$ & $33.4(23.6)^{c}$ & $22.6(5.7)^{\mathrm{a}}$ & $14.1(3.1)^{\mathrm{a}, \mathrm{b}}$ & 46.51 & $<0.001$ \\
\hline "Carbon (\%) & $1.73(1.11)^{a}$ & $2.21(1.18)^{a}$ & $2.48(1.95)^{a}$ & $1.67(0.59)^{\mathrm{a}}$ & $0.48(0.10)^{b}$ & 36.36 & $<0.001$ \\
\hline Nitrogen (\%) & $0.06(0.03)$ & $0.06(0.02)$ & $0.06(0.03)$ & $0.07(0.03)$ & $0.06(0.01)$ & 0.41 & n.s. \\
\hline $\mathrm{C} / \mathrm{N}$ ratio & $33.68(24.39)^{a}$ & $44.11(33.04)^{a}$ & $43.44(37.33)^{a}$ & $26.33(10.03)^{a, b}$ & $8.17(1.62)^{a, b}$ & 5.44 & $<0.001$ \\
\hline $\mathrm{pH}$ & $4.55(0.63)^{\mathrm{a}}$ & $4.76(0.45)^{\mathrm{a}}$ & $4.58(0.61)^{\mathrm{a}}$ & $4.88(0.82)^{\mathrm{a}}$ & $7.24(0.86)^{\mathrm{b}}$ & 44.49 & $<0.001$ \\
\hline
\end{tabular}

"a, b and c" indicate different groups after SNK or Dunn's tests $(P<0.05)$. Asterisks indicate those comparisons made with Kruskal-Wallis test.

Table 2. Habitat diversity on each LUU based on dominant soil use

\begin{tabular}{|c|c|c|c|c|c|}
\hline Soil-use diversity & LUU1 & LUU2 & LUU3 & LUU5 & LUU6 \\
\hline Closed wood & 8 & 11 & 4 & 4 & \\
\hline Open wood & 3 & 5 & 9 & 6 & \\
\hline Shrub area & 3 & & & 1 & \\
\hline Pasture & & & 3 & 5 & \\
\hline Grassland & 2 & & & & \\
\hline Agriculture & & & & & 16 \\
\hline Diversity & 1.78 & 0.95 & 1.42 & 1.81 & 0.00 \\
\hline
\end{tabular}

Numbers indicate number of sampling points at each soil-use type.

Table 3. Collembola abundances and diversity descriptors in the different LUUs. For abundance and number of taxa also average values (SD).

\begin{tabular}{llllllll}
\hline & LUU1 & LUU2 & LUU3 & LUU5 & LUU6 & F or H & $p$ \\
\hline Abundance & 1119 & 185 & 723 & 486 & 267 & & \\
Average abundance (SD) & $69.9(73.2)^{\mathrm{a}}$ & $16.8(27.3)^{\mathrm{b}}$ & $45.2(64.5)^{\mathrm{a}, \mathrm{c}}$ & $30.4(41.4)^{\mathrm{a}, \mathrm{b}, \mathrm{c}}$ & $16.7(17.8)^{\mathrm{b}, \mathrm{c}}$ & 5.36 & $<0.001$ \\
Number of taxa & 38 & 19 & 32 & 29 & 10 & & \\
Average number of taxa (SD) & $8.1(3.6)^{\mathrm{a}}$ & $3.5(3.0)^{\mathrm{b}, \mathrm{c}}$ & $6.3(2.8)^{\mathrm{a}, \mathrm{b}}$ & $5.3(2.5)^{\mathrm{a}, \mathrm{b}, \mathrm{c}}$ & $2.6(1.0)^{\mathrm{c}}$ & $30.15^{*}$ & $<0.001$ \\
Species richness (Margalef) & 5.27 & 3.45 & 4.71 & 4.53 & 1.61 & & \\
Species diversity (Shannon-Wiener) & 3.65 & 3.44 & 3.54 & 3.35 & 1.62 & & \\
Evenness (Pielou) & 0.69 & 0.81 & 0.71 & 0.69 & 0.49 & &
\end{tabular}

"a, b and c" indicate different groups after SNK or Dunn's tests $(P<0.05)$. Asterisks indicate those comparisons made with Kruskal-Wallis test.

number of species recorded, whereas LUU2 and LUU6 were those sites that presented the lowest abundance and number of species, respectively (Table 3). Significant differences were obtained for these two variables, however the definition of post hoc groups was difficult due to the great variation observed in all comparisons made.

The variation pattern observed in the number of taxa between the different LUUs is well reflected in the species richness (Margalef) values, with a pronounced decrease in both LUU2 and LUU6. Conversely, for species diversity (Shannon-Wiener), a decrease was only obtained for LUU6 (Table 3); the unexpected value of LUU2 is due to the high evenness.

In terms of the taxonomic profile, and with the exception of LUU2, Isotomidae dominated in terms of abundance, representing between $41.4 \%$ of the 


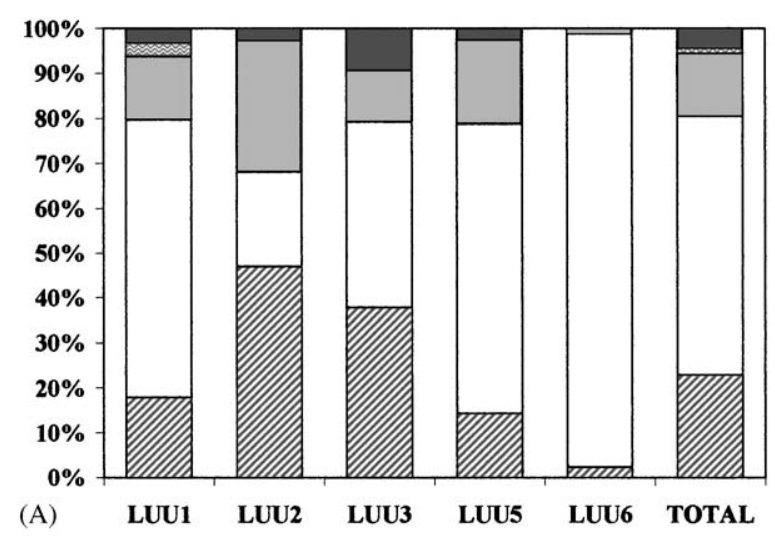

\section{Abundance}

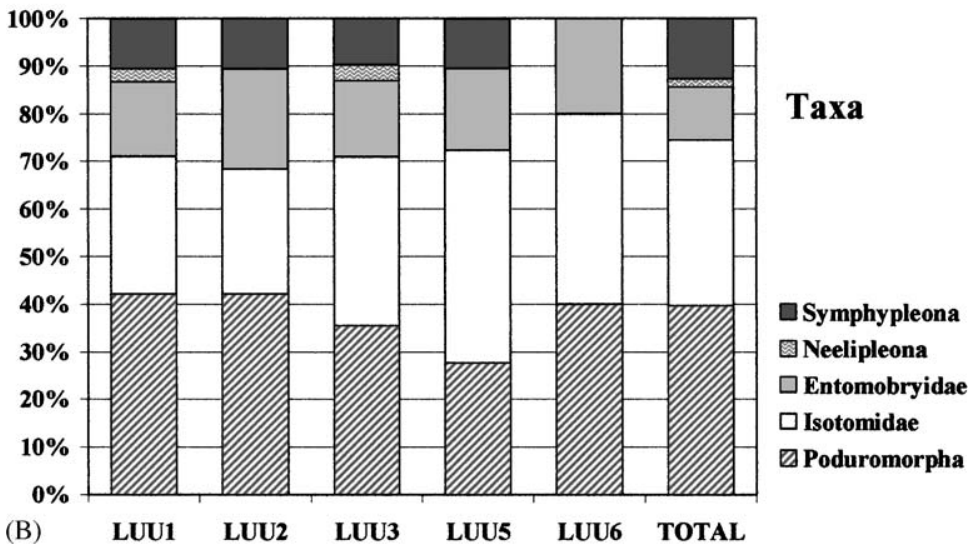

Figure 1. Community taxonomic profile (percentage of the different groups) from each LUUs and the overall data based on: (A) abundance and $(B)$ number of taxa.

specimens in LUU3 to $96.6 \%$ in LUU6 (Fig. 1a). Overall, this group accounted for $57.6 \%$ of individuals counted. The most abundant and most frequent species was Cryptopygus thermophilus (763 individuals in 45 sampling points), appearing in all LUUs (see the appendix). At a lower level of abundance (between 100 and 160 individuals), this species was followed by other Isotomidae ( $C$. ponticus, C. scapelliferus, Proisotoma minuta, Folsomides parvulus, C. debilis), and also by members of other families (e.g., Pseudostachia populosa, Heteromurus major, Xenylla brevisimilis mediterranea, Mesaphorura spp. and Entomobrya multifasciata). These last four species were also frequent, having an ubiquitous distribution among all LUUs. The overall community was dominated by a relatively small number of generalist species; in fact these 11 taxa (almost 20\% of the species) represented more than $77 \%$ of the total abundance. Moreover, almost $50 \%$ of the species were represented by five or less individuals.

In terms of number of taxa, the taxonomic spectrum is more balanced, with Poduromorpha dominating in most LUUs and in the overall community, with values around $40 \%$, closely fol- lowed by Isotomidae (Fig. 1b). The exception was LUU5, where this last family group dominated with $44.8 \%$ of the species against $27.6 \%$ from the Poduromorpha.

\section{Collembola: changes in species composition among LUUs}

The CCA, based on the species composition of the different LUUs, revealed a clear separation between the agricultural site (LUU6) and the others along canonical axis 1 (explaining $41.7 \%$ of the variability) (Fig. 2). The relevant species associated with this unit are $F$. parvulus (Fpa), very frequent but exclusive to this site, $C$. thermophilus (Cth) and C. ponticus (Cpo), species appearing frequently in all sites.

The second canonical axis (explaining $27.0 \%$ of the variation) separates the other sites. On the negative side of this axis we can find those units dominated by closed woodland (LUU1 and LUU2), whereas on the positive side are those sites where a more open landscape (open woodland or pastures) dominates (LUU3 and LUU5). Species mainly 


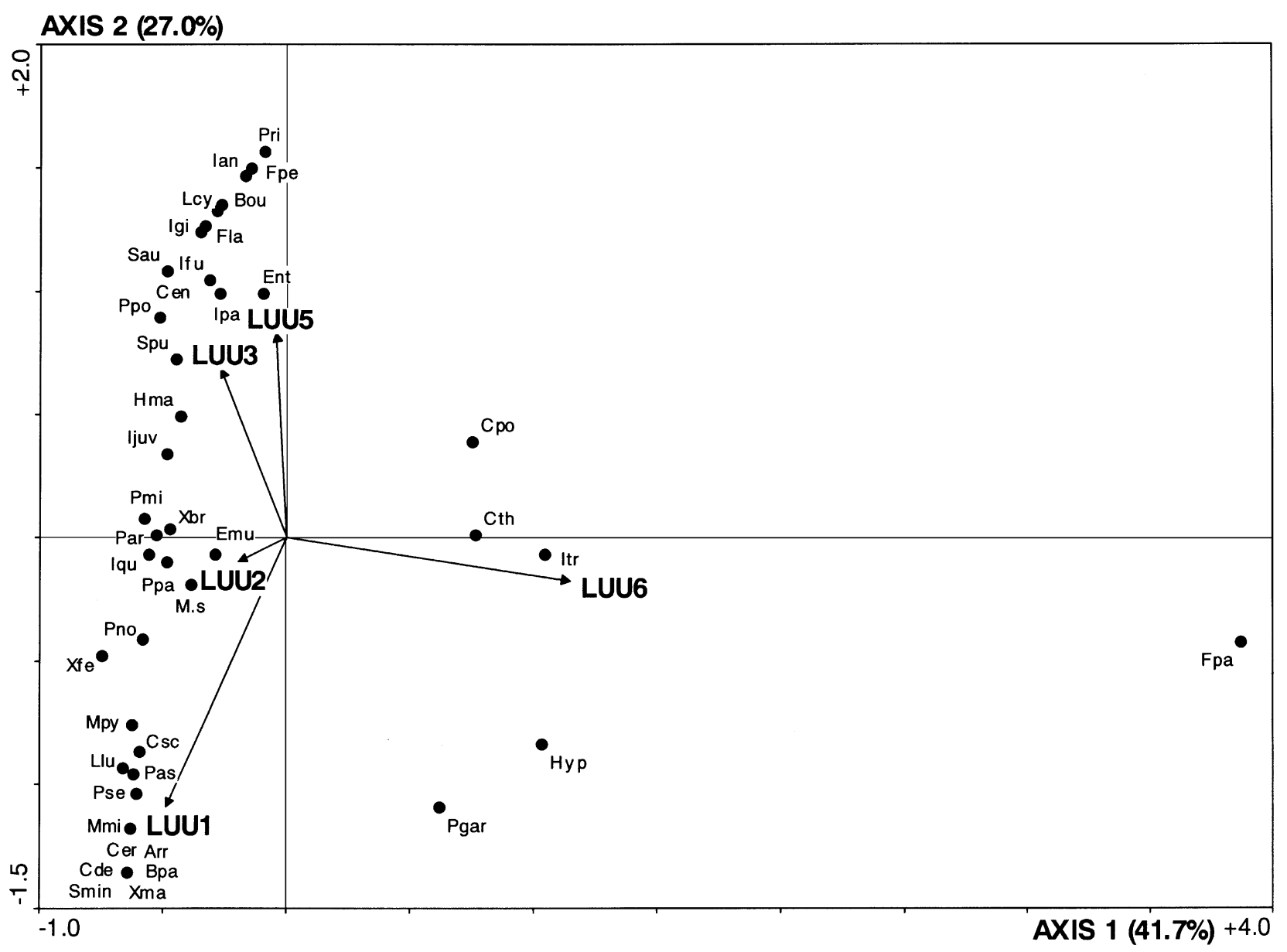

Figure 2. CCA based on community composition of the different LUUs. Significance of canonical axes: axis $1(F=5.12$, $P<0.01)$, other axes $(F=2.56, P<0.01)$. For species codes see the appendix.

associated with LUU1 are those appearing only in this site or with a very low abundance in other sites, like Arrhopalites sp. (Arr), C. debilis (Cde), Megalothorax minimus (Mmi), Pseudosinella sp. (Pse) and C. scapelliferus (Csc). The species Lepidocyrtus lusitanicus (Llu) and Micranurida pygmaea (Mpy) are also associated to LUU1, but since they are present a considerable abundance on LUU2, they are also included in the group of species associated with this site. This group also comprises Xenylla fernandesi (Xfe), a species occurring only in this unit. More to the centre of the axis it is possible to find those species with a more ubiquitous distribution among the LUUs. This group embodies species like Mesaphorura sp. (M.s), Pseudachorutes parvulus (Ppa), X. brevisimilis mediterranea (Xbr), Protaphorura armata (Par), E. multifasciata (Emu) and $H$. major (Hma).

Species mainly associated to LUU3 and LUU5 appear on the positive side of axis 2. Species like Ceratophysella engadinensis (Cen), Sminthurinus aureus (Sau), P. populosa (Ppo), P. minuta (Pmi) and
Sphaeridia pumilis (Spu) appear exclusively or clearly dominate in LUU3, whereas $F$. petiti (Fpe) and $P$. ripicola (Pri) dominate in LUU5. Common species to these two open landscape units are the taxa Entomobryidae juv. (Ent), Isotomurus fucicola (Ifu) and L. cyaneus (Lcy).

The differences in species composition between LUUs is confirmed by the SIMAN analysis $(F=20.26$, $P<0.001)$. Dunnet test revealed significant differences between LUU1 (considered here as the reference site) and all the other sites (Fig. 3). Differences were higher in LUU6 (lowest average inter-site similarity values), revealing more discrepancies in species composition in relation to the reference site.

\section{Collembola: changes in species composition among soil-use types}

To better understand the differences in community composition among land-use units, another CCA 


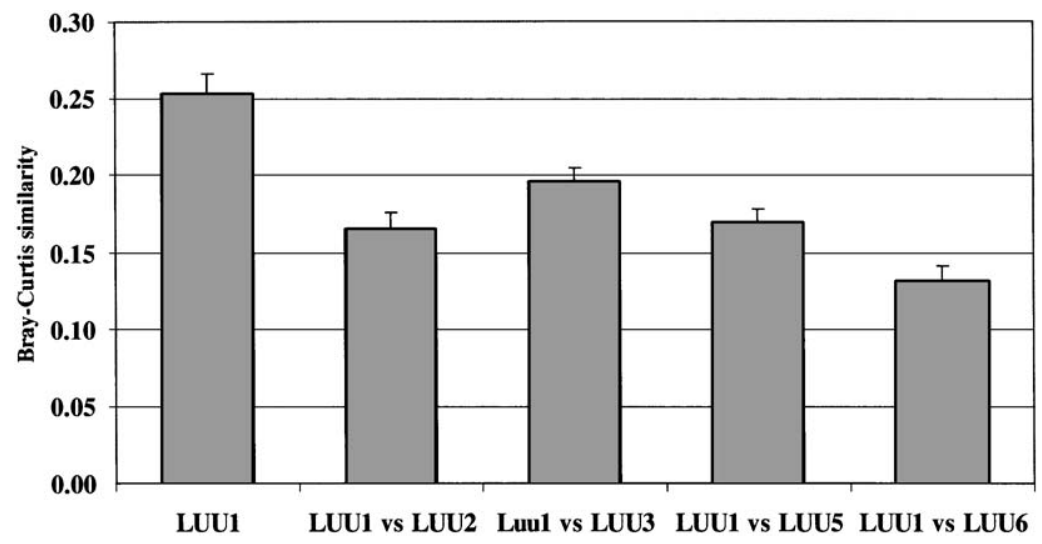

Figure 3. SIMAN analysis on the different LUUs. Similarity values (average+SD) on reference and treatment groups (see text for details).

AXIS 2 (22.1\%)

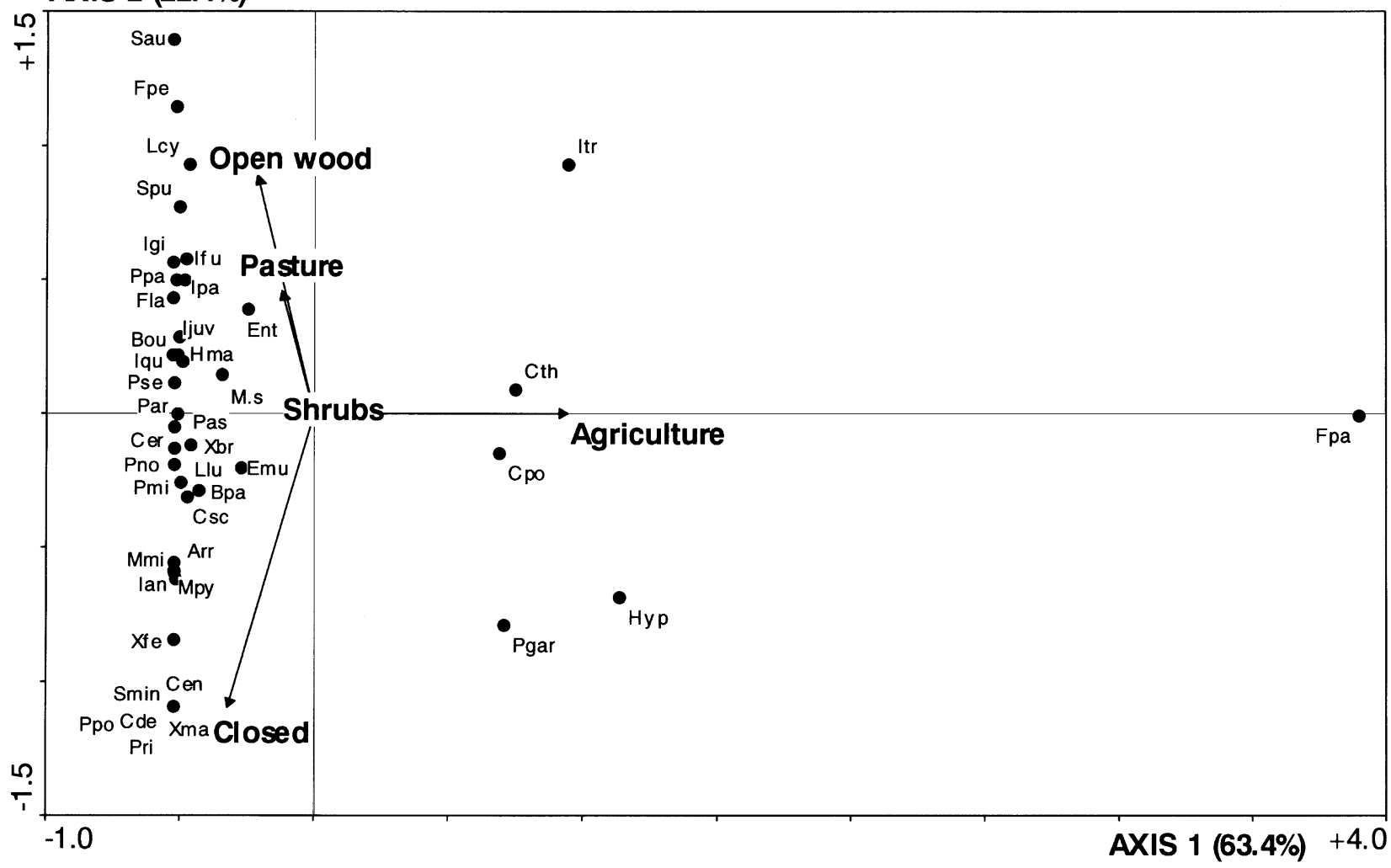

Figure 4. CCA based on community composition of the different soil-use types (see text). Significance of canonical axes: axis $1(F=5.09, P<0.01)$, other axes $(F=2.09, P<0.01)$. For species codes see the appendix.

was performed, based on the species assemblages existing at each dominant soil-use type (Fig. 4). The question was to check if differences in species composition between different soil-use types could account for the differences in species assemblages observed between LUUs.

As expected, canonical axis 1 (63.4\% of variability) separates the agricultural field from the other types of soil use. This corresponds to the entire LUU6, and the species associated to this soiluse type are the ones mentioned before for this site (see previous section and Fig. 2). Axis 2 (22.1\% of variability) separates taxa along a gradient ranging from closed woodland areas, on the negative side, to pastures/grassland and open woodland areas in the extreme positive side (Fig. 4).

Associated to closed cork-oak areas are species only existing or dominating in this type of soil use: 
Table 4. Abundance and number of taxa (average and SD) on the different soil-use types at each LUU

\begin{tabular}{|c|c|c|c|c|c|c|c|c|c|}
\hline & & Closed wood & Open wood & Shrub area & Pasture & Grassland & Agriculture & Forested areas & Open areas \\
\hline \multirow[t]{2}{*}{ LUU1 } & Abundance & $111.5(84.1)$ & $40.3(26.5)$ & $13.7(8.5)$ & & $32.5(23.3)$ & & 92.1 (78.7) & $21.2(16.7)$ \\
\hline & Taxa & $10.4(2.7)$ & $8.0(3.5)$ & $4.0(1.0)$ & & $4.5(0.7)$ & & 9.7 (2.9) & $4.2(0.8)$ \\
\hline \multirow[t]{2}{*}{ LUU2 } & Abundance & $22.4(33.6)$ & $7.0(6.1)$ & & & & & $16.8(27.3)$ & \\
\hline & Taxa & $4.1(3.7)$ & $2.5(1.0)$ & & & & & $3.5(3.0)$ & \\
\hline \multirow[t]{2}{*}{ LUU3 } & Abundance & $76.5(83.1)$ & $41.0(66.0)$ & & $16.0(10.8)$ & & & $51.9(70.1)$ & $16.0(10.8)$ \\
\hline & Taxa & $8.0(2.2)$ & $6.0(3.2)$ & & $5.0(1.0)$ & & & $6.6(3.0)$ & $5.0(1.0)$ \\
\hline \multirow[t]{2}{*}{ LUU5 } & Abundance & $56.0(72.1)$ & $19.7(18.8)$ & $83.0(0.0)$ & $12.2(8.8)$ & & & $34.2(38.1)$ & $24.0(30.0)$ \\
\hline & Taxa & $6.3(3.1)$ & $4.8(2.9)$ & $5.0(0.0)$ & $5.2(2.3)$ & & & $5.4(2.9)$ & $5.2(2.0)$ \\
\hline \multirow[t]{2}{*}{ LUU6 } & Abundance & & & & & & $16.7(17.8)$ & & 16.7 (17.8) \\
\hline & Taxa & & & & & & $2.6(1.0)$ & & $2.6(1.0)$ \\
\hline
\end{tabular}

C. debilis (Cde), P. populosa (Ppo) and X. fernandesi (Xfe), M. minimus (Mmi), M. pygmaea (Mpy) and $C$. engadinensis (Cen). The group including these taxa is heterogeneous, having representatives of dominant species from almost all LUUs.

A similar situation happens with those species having a more central position along axis 2 ; these are species existing mainly on both closed and open woodland areas (P. minuta - Pmi, L. lusitanicus Llu, P. armata - Par, E. multifasciata - Emu and $H$. major - Hma), or abundant in all soil-use types (C. thermophilus - Cth, C. ponticus - Cpo, C. scapelliferus - Csc, Mesaphorura sp. - M.s and $X$. brevisimilis mediterranea - Xbr). Some of these species have an ubiquitous distribution among all LUUs, others are dominant in a particular LUU.

Those species mainly associated with open areas (pasture or grassland and open oak woodland) are placed on the far positive side along axis 2 (Fig. 4): e.g., F. petiti (Fpe), S. pumilis (Spu), I. fucicola (Ifu), L. cyaneus (Lcy) and S. aureus (Sau). These are species mainly dominating or most abundant in LUU3 and LUU5 as mentioned earlier. The homogeneity of this group was expected since these two LUUs are dominated by these two soil-use types (see Table 2).

\section{Collembola: species richness and habitat diversity}

To analyse the relation between Collembola diversity descriptors and the habitat diversity (see Table 2) at each LUU, the Pearson moment correlation was calculated between these two sets of variables. Positive and significant correlations were found between habitat diversity and the total number of taxa identified $(r=0.93, P<0.05)$, Shannon-Wiener $(r=0.89, P<0.05)$ and the Marga- lef index values $(r=0.97, P<0.01)$. Also positive, but non-significant, was the correlation with the average number of taxa $(r=0.84$, n.s. $)$.

To identify changes in species richness and abundance among soil-use types inside each LUU, the average number of taxa and the average abundance were calculated (Table 4). Average species richness and abundance are always higher in closed woodland than in other soil-use types in almost all LUUs (the exception happened in LUU5 where shrub areas presented an higher mean abundance than other soil-use types). This difference is more evident in LUU1, where open habitats have, on average, half of the species when compared to woodland areas (Table 4). These do not represent new species, but only those that are able to be present in open habitats, although in lower number. This difference, however, becomes smaller as one moves to land-use units with higher representation of open habitats. This indicates that more and different species were able to colonise these open habitats, which corroborates the findings reported above when analysing species composition on the different soil-use types inside each LUU.

\section{Discussion}

\section{Changes in Collembola community composition}

The Collembola community in the study area was strongly dominated by Isotomidae (with more than $50 \%$ of the specimens identified and $35 \%$ of species collected), and Poduromorpha (with $40 \%$ of species richness). A similar pattern is reported by LaugaReyrel and Deconchat (1999) for oak coppice 
forests in southern France. Dominant Isotomid species presented a high reproductive rate, confirmed by the large number of juveniles found. This feature allowed some of them (e.g., C. thermophilus, $C$. scapelliferus, $C$. ponticus, $P$. minuta and $F$. parvulus) to colonise open/exposed areas with more unstable microhabitat conditions. Also frequent, and colonising open habitats, were several Entomobryidae and Sminthuridae species (E. multifasciata, $H$. major and S. pumilis), and even some Poduromorpha (Mesaphorura sp. and $X$. brevisimilis mediterranea). Some of these taxa were reported to be able to live in more unstable conditions (Sousa and Gama, 1994; Sousa et al., 1997) and X. brevisimilis mediterranea is characteristic of Mediterranean sclerophyllous oak coppices (Cortet and Poinsot-Balaguer, 1998).

Species composition from LUU6 clearly detached from the other units. The impoverished community, in comparison to the other LUUs, was expected mainly due to the fact that this is an agricultural land-use unit. Number of species, diversity and species richness were in the same order of magnitude as those reported for other crop systems by Alvarez et al. (2001). Abundance, however, was below the values reported by the some authors (Petersen, 2000; Frampton and Van den Brink, 2002) who did not find any significant decrease in Collembola populations in agricultural fields when compared to forest sites. Possible causes could be related to the type of soil and soil quality (low carbon and nitrogen contents, high $\mathrm{pH}$ ), diel activity patterns and time of sampling (Frampton et al., 2001), but especially to intensive management, particularly the frequent disturbance due to machinery use (alfalfa is mown several times during the year). This last factor is known to cause strong reductions in Collembola abundance (Heisler and Kaisser, 1995), and in this case only two species ( $F$. parvulus and $C$. scapelliferus) were able to adapt to this cycle of disturbance.

Regarding other units, LUU1 was where most species and most individuals were identified. The highest diversity and species richness values were also found here. This was derived mainly from the species composition of the forested patches, especially those covered with closed cork-oak formations. The well structured understory vegetation, together with the good quality of the soil, particularly the thickness of organic horizon (see Table 1), contributed to the existence of favourable ecological conditions for Collembola (Cortet and Poinsot-Balaguer, 1998; Hasegawa, 2002). Species assemblages in LUU2, an unit dominated mainly by closed cork-oak areas devoted to cork production, present some resemblance with the one from LUU1.
Although much poorer, species composition in this unit is composed mostly by common species found on LUU1; the most representative species is $X$. fernandesi, which seems to replace the abundant $X$. brevisimilis mediterranea in this site. The somehow unexpected low Collembola diversity and abundance in this land-use unit, when compared to LUU1, can be partially attributed to the low water content of the soil (see Table 1); this unit was sampled latter in the season, when air temperature and soil dryness were already high.

LUU5 and LUU3 were in the other extreme of the spectrum. Dominant Collembola species in these units were those mentioned above, with an ubiquitous distribution and also found in closed areas of other LUUs. However, several other species, capable of adapting to unstable conditions, were identified in these open areas, making their composition different from those of LUU1 and LUU2 and reducing the difference between the number of species in open and closed areas (see Table 4). Soil use in these units is dominated by pastures for wintering cattle. Grazing pressure is higher in LUU5 (more pasture area), and it is extended to open cork-oak patches. The shrub cover of these areas is reduced and they are also submitted to periodical reseeding with pasture vegetation.

The analysis and interpretation of the collected data reflects the dichotomy between closed and open areas, frequently reported by other authors (Bonnet et al., 1976, 1977; Ponge, 1980, 1993). However, differences in species composition among the several land-use units are not explained only by this division; as we documented, the proportion of each soil-use type within each land-use unit, plus the different management practices adopted also have a share in conditioning community composition.

Besides the strong anthropogenic pressure existing in the agricultural plot, all other plots were submitted to several types of disturbances. One, common to the forest plots, is the cork removal (every 9 years). Another, visible in LUU2, is pruning and a third one, common to the open areas of LUU3 and LUU5, is the preparation of the soil for growing species (which implies cutting the shrub layer, fertilising and planting every 7 years). This last one has a lower spatial extent, but a higher intensity. Moreover, these pasture and open woodland areas are also submitted to periodic grazing.

Bengtsson (2002) defines the first two types of disturbances as pulse disturbances and the last as a press disturbance. Resilience of soil communities will depend mainly on the intensity of the perturbation and, particularly in the case of pulse 
disturbances, on the evolution of the new habitat configuration in providing favourable conditions for the establishment of species. The structure of the community is also depending on the time passed since the disturbance. Usually the re-establishment of species in intervened areas is a dynamic process taking a long time, depending on their dispersal ability (Bengtsson et al., 1994a, b; Ojala and Huhta, 2001; Wanner and Dunger, 2002), the existence of donor areas in the vicinity, and the non-existence of disturbance in the meantime. In the case of cyclic disturbances (e.g., grazing) some species are able to adapt their dynamics to cope with this disturbance. However, when pulse and press disturbances coexist, community composition can be affected which usually results in a reduction of species number and/or abundance. In this case, and despite the slight difference in the average number of taxa between pasture and forest areas in LUU3 and LUU5, the abundance is still lower in open areas; moreover the species contributing to the decrease of that difference have a low abundance in comparison to more common species.

\section{Collembola as bioindicators of land-use change}

Returning to the main question addressed in the introduction, data collected revealed that Collembola reacted to changes in landscape structure. Shifts in species composition observed along the landscape units were mainly connected to differences in soil use, to changes in the proportion that different soil-use types occupy in each unit, and also to the management practices adopted on each site. Without diminishing the importance of natural perturbations in this type of ecosystem (e.g., natural fires, drought), man-induced disturbances could be considered the key factor influencing community structure of soil species. From the above-mentioned "triad" of environmental aspects, management practices adopted will dictate the extension, the intensity and the frequency of disturbances, and implicitly, they will have a major contribution in shaping the landscape and in configuring the different habitat types.

When using bioindicators like Collembola to monitor these changes, the "community" approach together with multivariate methods gives robust results, allowing the detection of small changes in community composition (Van Straalen, 1997, 1998). However, predictions and/or generalisations to other systems should be done carefully since soil animal communities are ruled by a plethora of ecological factors not directly related to anthropogenic pressures. This last point stresses the importance of the type of data to collect when using bioindicators to assess changes at landscape level. Besides data on landscape structure (gathered, for instance, by remote sensing techniques) and information on management practices and soiluse intensity, the interpretation of results improves when incorporating data on habitat configuration (e.g., vegetation cover and vegetation structure data).

\section{Acknowledgements}

This study was sponsored by the EU, integrated in the BIOASSESS project (Contract No.: EVK4 - 199900280). The authors would like to thank the Administration of Companhia das Lezírias (in the person of Eng ${ }^{\circ}$ Sérvulo Correia) and the Força Aérea Portuguesa - Campo de Tiro de Alcochete (in the person of Cmte Norte Jacinto) for allowing the realisation of the field work.

\section{Appendix}

Collembola species identified in the different LUUs are listed below.

\begin{tabular}{|c|c|c|c|c|c|c|c|}
\hline \multirow{10}{*}{$\begin{array}{l}\text { Family } \\
\text { HYP }\end{array}$} & Codes & Taxa & LUU1 & LUU2 & LUU3 & LUU5 & LUU6 \\
\hline & Cen & Ceratophysella engadinensis Gisin, 1949 & & & 11 & & \\
\hline & $\mathrm{Ctu}$ & Ceratophysella tuberculata Cassagnau, 1959 & & & & 1 & \\
\hline & Cer & Ceratophysella juv. & 3 & & & & \\
\hline & Нyp & Hypogastrura juv. & 4 & 1 & & & 2 \\
\hline & Hve & Hypogastrura vernalis (Carl, 1901) & & & & & 1 \\
\hline & Xbr & Xenylla brevisimilis mediterranea Gama, 1964 & 47 & 9 & 33 & 47 & \\
\hline & $X f e$ & Xenylla fernandesi Gama, 1974 & & 47 & & & \\
\hline & Xma & Xenylla maritime Tullberg, 1869 & 6 & & & & \\
\hline & Xar & Xenyllodes armatus Axelson, 1903 & 2 & & & & \\
\hline
\end{tabular}




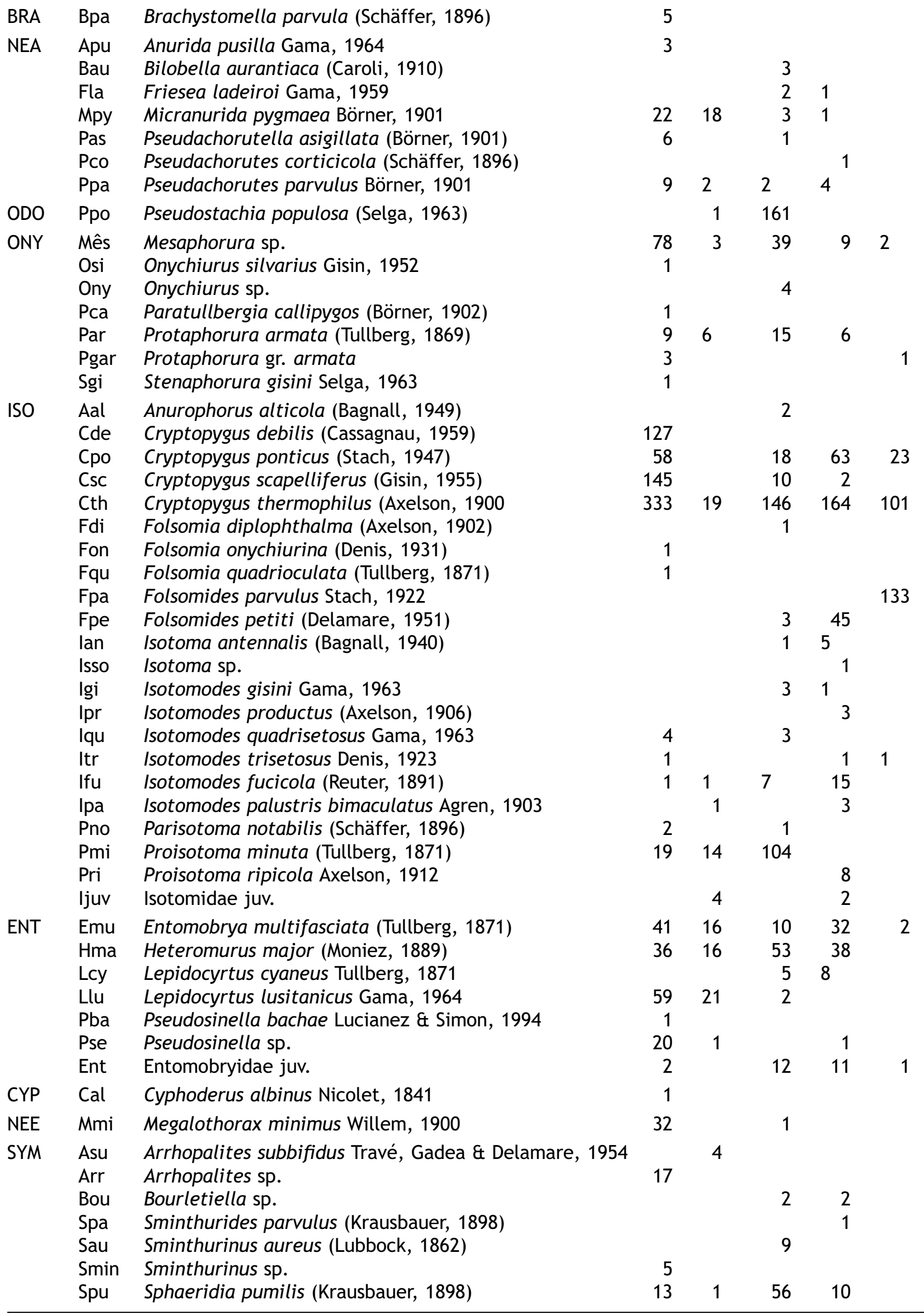




\section{References}

Alvarez, T., Frampton, G.K., Goulson, D., 2000. The role of hedgerows in the recolonisation of arable fields by epigeal Collembola. Pedobiologia 44, 516-526.

Alvarez, T., Frampton, G.K., Goulson, D., 2001. Epigeic Collembola in winter wheat under organic, integrated and conventional farm management regimes. Agr. Ecosyst. Environ. 83, 95-110.

Barrocas, H.M., Gama, M.M.da., Sousa, J.P., Ferreira, C.S., 1998. Impact of reafforestation with Eucalyptus globulus Labill. on the edaphic collembolan fauna of Serra de Monchique (Algarve, Portugal). Misc. Zool. 21, 9-23.

Bengtsson, J., 2002. Disturbance and resilience in soil animal communities. Eur. J. Soil Biol. 38, 119-125.

Bengtsson, G., Hedlund, K., Rundgren, S., 1994a. Foodand density-dependent dispersal: evidence from a soil collembolan. J. Anim. Ecol. 63, 513-520.

Bengtsson, G., Rundgren, S., Sjögren, M., 1994b. Modelling dispersal distances in a soil gradient: the influence of metal resistance, competition, and experience. Oikos 71, 12-23.

Bengtsson, J., Persson, T., Lundkvist, H., 1997. Longterm effects of logging residue addition and removal on macroarthropods and enchytraeids. J. Appl. Ecol. 34, 1014-1022.

Benito, J.C.S., Sanchez, M.J.L., 2000. Ecology of soil springtails (Collembola, Insecta) from pine woods and Rhododendron shrublands in the Central and Eastern Pyrenees (North Spain). Pedobiologia 44, 430-441.

Bonnet, L., Cassagnau, P., Deharveng, L., 1976. Un exemple de rupture de l'équilibre biocénotique par déboissement: Les peuplements de Collemboles édaphiques du Piau d'Engaly (Hautes-Pyrénees). Rev. Ecol. Biol. Sol 13, 337-351.

Bonnet, L., Cassagnau, P., Deharveng, L., 1977. Influence du déboisement et du reboisement sur les biocénoses de Collemboles dans quelques sols Pyrénéens. B. Ecol. 8, 321-332.

Chagnon, M., Hebert, C., Pare, D., 2000. Community structures of Collembola in sugar maple forests: relations to humus type and seasonal trends. Pedobiologia 44, 148-174.

Cortet, J., Poinsot-Balaguer, N., 1998. Collembola populations under sclerophyllous coppices in Provence (France): comparison between two types of vegetation, Quercus ilex L. and Quercus coccifera L. Acta Oecol. Int. J. Ecol. 19, 12.

Deharveng, L., 1996. Soil collembola diversity, endemism and reforestation: a case study in Pyrenees (France). Conserv. Biol. 10, 74-84.

Dekkers, T.B.M., Van der Werff, P.A., Van Amelsvoort, P.A.M., 1994. Soil Collembola and Acari related to farming systems and crop rotations in organic farming. Acta Zool. Fenn. 195, 28-31.

Diaz, M., Campos, P., Pulido, F.J., 1997. The Spanish dehesa: a diversity in land use and wildlife. In: Pain, D.J., Pienkowski, M.W. (Eds.), Farming and Birds in Europe. The Common Agricultural Policy and its implications for bird conservation. Academic Press, London, pp. 178-209.

Dombos, M., 2001. Collembola of loess grassland: effects of grazing and landscape on community composition. Soil Biol. Biochem. 33, 2037-2045.

Faith, D.P., Minchin, P.R., Belbin, L., 1987. Compositional dissimilarity as a robust measure of ecological distance. Vegetatio 69, 57-68.

Filser, J., Fromm, H., Nagel, R.F., Winter, K., 1995. Effects of previous intensive agricultural management on microorganisms and the biodiversity of soil fauna. Plant Soil 170, 123-129.

Filser, J., Lang, A., Mebes, K.-H., Mommertz, S., Palojärvi, A., Winter, K., 1996. The effect of land use change on soil organisms - an experimental approach. Verh. Ges. Ökol. 26, 671-679.

Frampton, G.K., 2000. Recovery responses of soil surface Collembola after spatial and temporal changes in long-term regimes of pesticide use. Pedobiologia 44, 489-501.

Frampton, G.K., Van den Brink, P.J., 2002. Influence of cropping on the species composition of epigeic Collembola in arable fields. Pedobiologia 46, 328-337.

Frampton, G.K., Van den Brink, P.J., Wratten, S.D., 2001. Diel activity patterns in an arable collembolan community. Appl. Soil Ecol. 17, 63-80.

Gama, M.M.da., Vasconcelos, T.M., Sousa, J.P., 1994. Collembola diversity in Portuguese autochthonous and allochthonous forests. Acta. Zool. Fenn. 195, 44-47.

Gama, M.M.da., Sousa, J.P., Ferreira, C., Barrocas, H., 1997. Endemic and rare Collembola distribution in High Endemism Areas of South Portugal: a case study. Eur. J. Soil Biol. 33, 129-140.

Gardi, C., Tomaselli, M., Parisi, V., Petraglia, A., Santini, C., 2002. Soil quality indicators and biodiversity in northern Italian permanent grasslands. Eur. J. Soil Biol. 38, 103-110.

Hågvar, S., Abrahamsen, G., 1984. Collembola in Norwegian coniferous forest soils. III. Relations to soil chemistry. Pedobiologia 27, 331-339.

Hasegawa, M., 2002. The response of collembolan community to the amount and composition of organic matter of a forest floor. Pedobiologia 46, 353-364.

Heisler, C., Kaisser, E.-A., 1995. Influence of agricultural traffic and crop management on colembola and microbial biomass in arable soil. Biol. Fertil. Soils 19, 159-165.

Lauga-Reyrel, F., Deconchat, M., 1999. Diversity within the Collembola community in fragmented coppice forests in south-western France. Eur. J. Soil Biol. 35, 177-187.

Loranger, G., Ponge, J.-F., Blanchart, È., Lavelle, P., 1999. Influence of agricultural practices on arthropod communities in a vertisol (Martinique). Eur. J. Soil Biol. 34, 157-165.

Loranger, G., Bandyopadhyaya, I., Razaka, B., Ponge, J.F., 2001. Does soil acidity explain altitudinal sequences in collembolan communities? Soil Biol. Biochem. 33, 381-393. 
Magurran, A.E., 1991. Ecological Diversity and its Measurement. Chapman \& Hall, London.

Nakamura, Y., 1988. The effect of soil-management on the soil faunal makeup of a cropped andosol in central Japan. Soil Till. Res. 12, 177-186.

Ojala, R., Huhta, V., 2001. Dispersal of microarthropods in forest soil. Pedobiologia 45, 433-450.

Petersen, H., 2000. Collembola populations in an organic crop rotation: population dynamics and metabolism after conversion from clover-grass ley to spring barley. Pedobiologia 44, 502-515.

Pflug, A., Wolters, V., 2001. Influence of drought and litter age on Collembola communities. Eur. J. Soil Biol. 37, 305-308.

Pinto, C., Sousa, J.P., Graça, M.A.S., Gama, M.M.da., 1997. Forest Soil Collembola. Does tree introductions make a difference? Pedobiologia 41, 131-138.

Poinsot-Balaguer, N., 1975. Influence des facteurs abiotiques sur la dynamique des peuplements de Collemboles de la sansouire camarguaise. Ecol. Mediterr. 1, 193-201.

Ponge, J.F., 1980. Les biocénoses des collemboles de la forêt de Sénart. In: Pesson, P. (Ed.), Actualités d'Ècologie Forestière. Gauthier-Villars, Paris, pp. 151-176.

Ponge, J.F., 1993. Biocenoses of Collembola in atlantic temperate grass-woodland ecosystems. Pedobiologia $37,223-244$

Ponge, J.F., 2000. Acidophilic Collembola: living fossils? Contr. Biol. Lab. Kyoto Univ. 29, 65-74.

Ponge, J.F., Prat, B., 1982. Les Collemboles, indicateurs du mode d'humification dans les peuplements résineux, feuillus et málangés: résultats obtenus en forêt d'Orléans. Rev. Ecol. Biol. Sol 19, 237-250.

Ponge, J.F., Arpin, P., Vannier, G., 1993. Collembolan response to experimental perturbations of litter supply in a temperate forest ecosystem. Eur. J. Soil Biol. 29, 141-153.

Pozo, J., Selga, D., Simon, J.C., 1986. Studies on the collembolan populations of several plant communities of the Basque Country (Spain). Rev. Ecol. Biol. Sol 23, 215-232.

Pulido, F.J., Diaz, M., Trucios, S.J.H., 2000. Size structure and regeneration of Spanish holm oak Quercus ilex forest and dehesas: effects of agroforestry use on theirs long-term sustainability. Forest Ecol. Manag. 52, 1-13.

Reddy, V.S., Reddy, M.V., Lee, K.K., Rao, K.P.C., Sinivasan, S.T., 1996. Response of some soil mesoand macro-faunal populations to soil management during crop and fallow periods on a semi-arid tropical alfisol (India). Eur. J. Soil Biol. 32, 123-129.

Rohlf, F.J., 1997. NTSYS-pc (v.2.0). Numerical Taxonomy and Multivariate Analysis System. Applied Biostatistics Inc., New York.

Setälä, H., Marshall, V.G., Trofymow, J.A., 1995. Influence of micro- and macro-habitat factors on collembolan communities in douglas-fir stumps during forest sucession. Appl. Soil Ecol. 2, 227-242.

Sousa, J.P., Gama, M.M.da., 1994. Rupture in a Collembola community structure from a Quercus rotundifolia Lam. forest due to the reafforestation with Eucalyptus globulus Labill. Eur. J. Soil Biol. 30, 71-78.

Sousa, J.P., Vingada, J.V., Barrocas, H., Gama, M.M.da., 1997. Effects of introduced exotic tree species on Collembola communities: the importance of management techniques. Pedobiologia 41, 145-153.

Sousa, J.P., Gama, M.M.da., Ferreira, C., Barrocas, H., 2000. Effect of eucalyptus plantations on Collembola communities in Portugal: a review. Belg. J. Entomol. 2, 187-201.

SPSS, 1995. SigmaStat for Windows (version 2.03). SPSS Science, IL.

Ter Braak, C.J.F., Smilauer, P., 1998. CANOCO Reference Manual and User's Guide to CAnoco for Windows: Software for Canonical Community Ordination (version 4). Microcomputer Power, Ithaca, NY.

Van Straalen, N.M., 1997. Community structure of soil arthropods as a bioindicator of soil health. In: Pankhurst, C.E., Doube, B.M., Gupta, V.V.S.R. (Eds.), Biological Indicators of Soil Health. CAB International, Wallingford, pp. 235-264.

Van Straalen, N.M., 1998. Evaluation of bioindicator systems derived from soil arthropod communities. Appl. Soil Ecol. 9, 429-438.

Van Straalen, N.M., Verhoef, H.A., 1997. The development of a bioindicator system for soil acidity based on arthropod pH preferences. J. Appl. Ecol. 34, 217-232.

Verhoef, H.A., Van Selm, A.J., 1983. Distribution and population dynamics of Collembola in relation to soil moisture. Holarct. Ecol. 6, 387-394.

Vilkamaa, P., Huhta, V., 1986. Effects of fertilization and $\mathrm{pH}$ on communities of Collembola in pine forest soil. Ann. Zool. Fenn. 23, 167-174.

Wanner, M., Dunger, W., 2002. Primary immigration and succession of soil organisms on reclaimed opencast coal mining areas in eastern Germany. Eur. J. Soil Biol. 38, 137-143.

Zar, J.H., 1996. Biostatistical Analysis. Prentice-Hall International, London. 